\title{
An Integral Systems Theory Perspective of Interdisciplinary Collaboration: The Example of CATCH, a Capture-Based Aquaculture Research Project for Quality Norwegian Cod Products
}

\author{
Cheryl Marie Cordeiro, PhD
}

\author{
Researcher, \\ Nofima (Norwegian Institute of Food, \\ Fisheries and Aquaculture Research) \\ Muninbakken 9, 9291 Tromsø, Norway \\ Corresponding Author \\ Geir Sogn-Grundvåg, PhD \\ Senior Researcher, \\ Nofima (Norwegian Institute of Food, \\ Fisheries and Aquaculture Research) \\ Muninbakken 9, 9291 Tromsø, Norway
}

Doi: 10.2478/ajis-2019-0002

\begin{abstract}
Due to the increasing complexity of the global development challenges that need solving, the past thirty years have seen interdisciplinary research (IDR) and university-industry collaboration developing into its own subject of research. While there have been numerous studies on defining and evaluating IDR, what remains under-researched is a unifying or integral perspective in IDR theoretical framing and conceptualisation much due to the nature of the multiple disciplines that constitute IDR. This study takes an integral systems theory perspective in address of the knowledge-gap in IDR, using the example of the project $\mathrm{CATCH}$, a capture-based aquaculture research project funded by the Research Council of Norway and industry partners, for improved Norwegian cod products to local and global markets. The purpose of this study is to investigate and uncover the management strategies of the project $\mathrm{CATCH}$, with the goal of illustrating how elements of such a management strategy can be mapped unto a fourquadrant integral systems theory model towards a unified perspective of an IDR project. The United Nations Food and Agriculture Organization (FAO) has projected a 20\% growth in global fish production and consumption by 2030. CATCH, which is situated in the field of fisheries and aquaculture research, makes for a timely and interesting example of how an inherently IDR project is managed and executed by multiple stakeholders from academic institutions as well as industry partners. The contribution of this study is twofold, (i) working towards the consolidation of the theoretical foundations of IDR, and (ii) developing empirical insights into the management processes and strategy of an IDR project.
\end{abstract}

Keywords: interdisciplinary research, industry collaboration, integrated systems theory, fisheries and aquaculture, research methodology, project management

\section{Introduction}

The past thirty years have seen an increasingly awareness and interest in both interdisciplinary research (IDR) between different academic disciplines (Brown, 2018; Bark, Kragt \& Robson, 2016; Metzger \& Zare, 1999; Lemaine et al., 1976), and university-industry research collaboration for 
applied sciences (Banal-Estanol, Macho-Stadler \& Perez-Castrillo, 2018; Mascarenhas, Ferreira \& Marques, 2018; Scandura, 2016; Dooley \& Kirk, 2007; Lee, 2000). IDR refers to the integrative effort in assimilating and using methods, data, tools, concepts and theories from separate disciplines towards a common understanding of a complex socio-ecological challenge, where some scholars tend to equate IDR with transdisciplinary research (TDR) efforts (Stokols et al. 2008; Stokols et al., 2003). This developing interest in $\mathrm{IDR}^{1}$ as a subject of research is due to realisation that the increasingly complexity in solving global developmental and environmental challenges requires a holistic approach. IDR literature indicates that IDR is viewed as means to the emergence of new disciplines, as well as new knowledge production (Darbellay, 2015; Olsen et al, 2013a; Wesselink, 2009). Still, a continuing challenge to the study of IDR as a field of its own is indeed its multifaceted form (Huutoniemi et al., 2010; Qin, Lancaster \& Allen, 1997) with inherent multilevelled epistemological, structural and affective tensions (Turner et al., 2015). And while there exists a body of literature that focuses on the evaluation and measurement of the effectiveness of IDR (Bark, Kragt \& Robson, 2016; Fazey et al., 2014; Wagner et al., 2011; Klein, 2008) with various frameworks for structuring IDR (König et al., 2013; Roux et al., 2010; Dewulf et al., 2007), what remains under researched is the systemic conceptualisation towards an integrated systems perspective of IDR studies (Capra \& Luigi, 2014; Francois, 2006). Scholars have also called upon an increased effort in formulating a coherent research framework for IDR. This is due to that a broadly accepted and utilized research framework with consistently defined terms, concepts and language is yet to be developed (Brandt et al., 2013; Jahn, Bergmann \& Keil, 2012).

The subject of sustainable global food consumption in relation to the fisheries and aquaculture industry sector is particularly salient for IDR framing much due to the fact that global fish ${ }^{2}$ consumption is projected towards a $1.5 \%$ increase per year in the next coming decades, with global fish production and consumption projected to increase $20 \%$ by 2030 (FAO 2018). This study takes the multistakeholder IDR project entitled $\mathrm{CATCH}^{3}$, set within the context of the fisheries and aquaculture research and business sector in Norway in illustration of how an integrated systems theoretical perspective can be used to unfold the multiple stakeholder perspectives encompassed within such an IDR project. It offers a visual conceptualisation of the management of $\mathrm{CATCH}$, an applied sciences industry-university collaboration towards higher quality yield of capture-based aquaculture for cod, towards a pedagogical model of understanding and management of an IDR project in general.

This study addresses the knowledge gap in a unified theoretical framework for the field of IDR studies. The contribution of this study is twofold that includes, (i) consolidating the theoretical foundational knowledge of IDR through an integral systems theoretical perspective, and by using an empirical example of a project timely situated in a field that is inherently interdisciplinary in nature, with close industry collaboration, (ii) develop deeper insights into the management processes and strategy of an IDR project. The research questions (RQ) addressed in this study are:

RQ1: How can an integral systems theory perspective be used to map IDR project management strategies and processes from the different stakeholder perspectives?

RQ2: What project management strategies of IDR can be identified by applying an integral systems theory framework to an IDR project?

RQ3: By using CATCH as project example, what applied impacts on IDR research can be observed from framing IDR project management strategies through an integral systems approach?

The paper is structured as follows. A general literature review of integral systems theory is presented, followed by details of the case example of $\mathrm{CATCH}$ as an IDR project. The methods

\footnotetext{
${ }^{1}$ For the purposes of this paper, the term IDR is used to refer to both academic interdisciplinary research as well as industry-university research collaboration.

${ }^{2}$ The term 'fish' is used in accordance to the Food and Agriculture Organization of the United Nations (FAO 2018) definition referring to fish, crustaceans, molluscs and other aquatic animals. The term excludes aquatic mammals, reptiles, seaweeds and other aquatic plants. The term 'fish' is also used in synonymous exchange with the term 'seafood'.

${ }^{3}$ The IDR project CATCH ran between April 2014 and October 2018. The project was funded by the Norwegian Research Council, Project number 233751.
} 
section expands on the perspectives of the integral systems quadrants, and the elements of the management process of $\mathrm{CATCH}$ is mapped unto the four quadrant perspectives. This is followed by a discussion of findings / results, its implications for future IDR project management and avenues for future academic research in the field of IDR. The limitations of the study will also be discussed in the concluding section of the paper.

\section{Literature Review: An Integral Systems Theoretical Perspective to IDR}

While current social-ecological challenges require an integration and assimilation of multiple perspectives of investigation and an integrated systems approach to problem-solving, the scientific paradigm shift towards the increasing influence of systems thinking began in latter half of the 1900s as a response to the limitations of Descartes's analytic reason (Capra, 1985; von Bertalanffy, 1968). Strong systems thinking influences saw scholars shift their perspective from viewing the parts to viewing the whole as an open adaptive system, where it is also understood that the whole is greater than the sum of its parts (Capra \& Luigi, 2014; Floyd, 2008; Capra, 1997).

Fisheries and aquaculture research is inherently interdisciplinary and pluralistic in theoretical methods, the purpose of the research findings of which are usually intended to be applied to business sector practices. Challenges set in the context of the fisheries and aquaculture industry are inherently socio-ecologically complex, with a need to balance between socio-ecological and economic resources. Although many business enterprises within fisheries and aquaculture in particular the Norwegian context are born globals, being multinational enterprises, their business narratives continue to be marginal to the international business (IB) community of scholars whose theories focus much more on traditional manufacturing enterprises (Kay, 2018; Vahlne \& Johanson, 2017, 2013; Gibbons, 2005; Grossman \& Hart, 1986; Coase, 1937). Different from IB studies, fisheries and aquaculture international business (FAIB) has the task of considering carefully, the social contract between an enterprise and society (Thompson \& Valentinov, 2017; Lam, 2016; Villasante et al., 2011).

Maintaining socio-economic and ecological balance in any business sector is challenging, although in a field such as FAIB, there exists a much higher level of awareness of this social contract much due to that the availability of raw resources is in the long term, the sustainability and competitive of the enterprise in itself. Several studies that focus on the specific challenges that IDR research face, particularly IDR in the context of sustainability science have shown five key challenges that need to be addressed when doing IDR and university-industry collaboration. The first of these challenges is in effect, (i) a lack of coherent shared framing towards problem solving. This is perhaps an inherent challenge for IDR where scientists and practitioners are brought to the project for the very reason of their different knowledges and discipline backgrounds (Pischke et al., 2017; Bark, Kragt \& Robson, 2016; Brandt et al., 2013). This challenge leads to the second, which is (ii) the lack of an integration of methods between disciplines. Method integration would lead to new knowledge formation at the intersections of society and science in which sustainability challenges can be viewed in novel perspective and perhaps solved through applied innovation (Clark et al., 2017; Szostak, 2015). The third challenge to IDR is (iii) mapping the ongoing research processes and knowledge production so that it can be implemented in context. Scholars have identified and characterised three types of knowledges in IDR that include, systemic (gaining a broad overview of root causes and possible solutions to a socio-ecological challenge), specific (such as targeted towards problem solving in context) and transformative (knowledge acquired that can change the course of future action towards solving a current challenge) (Pohl \& Hirsch Hadorn, 2007). What remains is a deeper understanding of how these types of knowledges can be implemented in practice and effectively shared across disciplines (Adler et al., 2018; Pohl \& Hirsch Hadorn, 2008). Perhaps part of the challenge to the effective transfer of knowledge not only between IDR scholars but also from scholars to practitioners, could be attributed to (iv) the degree and intensity of practitioner engagement (Pischke et al., 2017; Brandt et al., 2013). In IDR projects, when projects are co-designed across disciplines, it is often the case that a project might be weighted heavier or grounded in one discipline and its connates. This means a varying degree of involvement between academics, as well as industry practitioners. In terms of industry partners, it 
might also be the case that due to the different (generally shorter) working timelines of the industry, that practitioners might not have as much time to commit to a single project as would a scholar to the same project. Practitioner contributions to an IDR project might range from consultant / adviser (outlining a context based socio-ecological problem currently faced) to beneficiary (if for example a new prototype product is built). The different practitioner roles and industry expectations would mean varying degrees of project participation at different stages of the project (Steinmo, 2015; Krütli et al., 2010). The final challenge characterised in IDR is (v) creating of social impact, where the fabric and landscape of sustainability sciences for example, is so nuanced that what research findings and outcomes intended originally for a broader global reach, is eventually confined to context specific solutions (Mårtensson et al., 2016; Brandt et al., 2013). There is also a current bias in IDR literature to favour quantitative measurements of social impact. In such an instance, scholars have called for a more nuanced, qualitative approach to the measuring of social impact, where shifts in opinions, practices and even values might be studied (Rau, Goggins \& Fahy, 2018).

Whilst there might be some ways to go before IDR challenges are resolved, inherent in an integral systems approach to IDR is the capacity to frame perspective relativity. Relativity in perspective is inherently structured in the lexico-grammar (architecture) of almost all human languages (Halliday \& Matthiessen, 2014; Roy et al., 2013; Chomsky, 2011). In the English language, perspective is reflected in the deictic (pointer) pronoun referencing system of the singular subjective (Iperspective), plural intersubjective (We-perspective), singular objective (It-perspective) and the plural interobjective (Its-perspective) (Halliday \& Matthiessen, 2014). The grammatical function of pronouns, "I", "We", "It" and "Its" translates into four perspectives that render four different types of knowledge zones (Bowman, 2012; Wilber 2000). It is this four quadrant perspectivising that is the integral systems approach to IDR, reflecting an integral worldview characterised by plurality in perspectives. For each of these perspectives, reflected in Figure 1, there is a further possibility to reference interior (I/We/lt/lts perspectives) and exterior (You/They/lt/lts perspectives) views even if in the English language, the reference words remain as It/lts for singular objective and plural interobjective views. Language in use both reflects and constructs our reality (Whorf \& Carroll, 1974). Knowledge zones are created when research studies consistently have as investigative focus, one of these perspectives. As such, Figure 1 also maps 8 major research methodological perspectives (EsbjornHargens \& Zimmerman, 2009; Wilber, 2006, 2000).

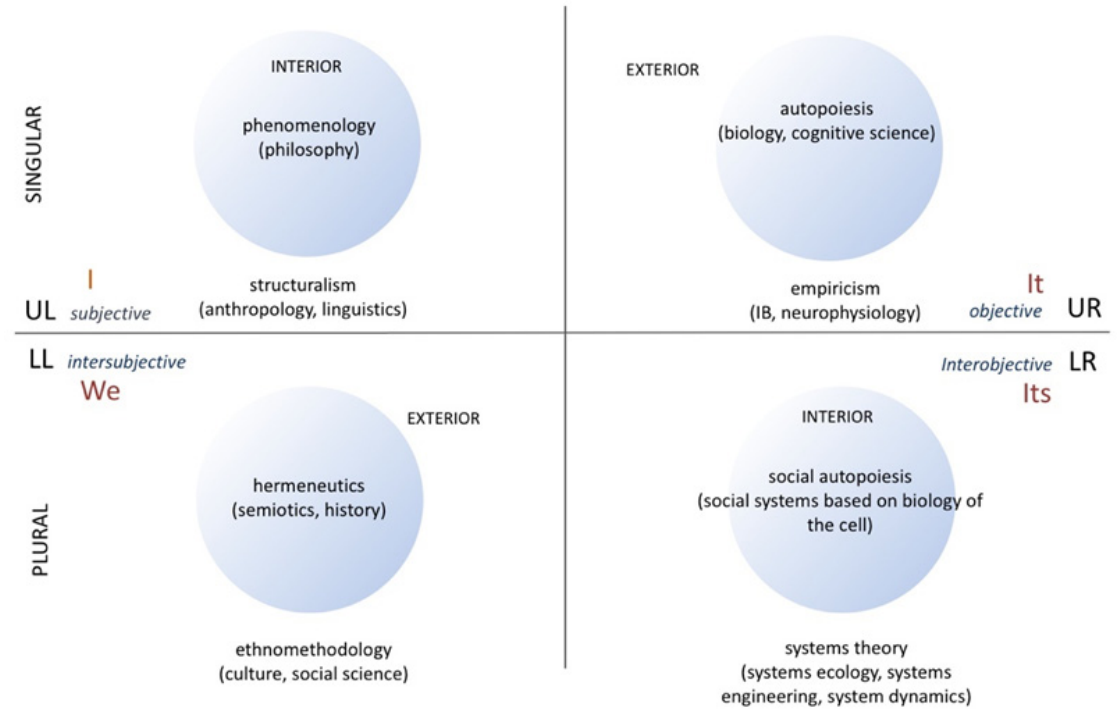

Figure 1. Integral four-quadrant model illustrating the English language deictic pronoun referencing system, mapping the 8 primordial perspectives and 8 major research methodological perspectives. 
The perspectives visualized in the quadrants in Figure 1 can be seen as holons ${ }^{4}$, moving from narrower to broader perspectives, with each broader perspective encompassing the narrower perspectives. Figure 1 also illustrates examples of dominant type methods of inquiry if consistent scientific inquiry were to be made from the perspectives of $I$, We, It and Its. The singular subjective perspective is expressed in the Upper Left (UL) quadrant which are I (interior) / You (exterior). In the UL quadrant, phenomenology, which is the study of consciousness, experience and intention as viewed from the first-person perspective directed towards an object/entity could be said to be an example of a consistent method of investigation employed in order to uncover knowledge in this quadrant. Also, from the $I$ perspective but with an understanding that phenomena of human life have meaning only through interrelations is reflected in the exterior view of $I$, where in some cases the pronoun You can be used to make a deictic distinction. Structural anthropology for example, which is the study of human behaviour and societies as having structural patterns and organization is an example of a type of knowledge that can be characterised in the UL quadrant. The plural intersubjective perspective is expressed in the Lower Left (LL) quadrant with the pronouns We (interior) and They (exterior). In the LL quadrant, a dominant theory and method of investigation for the interpretation of collective texts from society's perspective is hermeneutics, whilst an exterior view of We in the study of culture could employ methodologies such as ethnomethodology and discourse analysis of group interactions. Knowledge on in-group and out-group behaviour is characteristic of the LL quadrant, where relationships between social groups are studied and mapped. Going diagonally across Figure 1 from the LL quadrant, the singular objective perspective is expressed in the Upper Right (UR) quadrant with the pronouns It (interior) and It (exterior). While the English language does not make a spelling distinction between the two reference points, these reference points are nonetheless defined when studies are designed and reflected in their choice of methodology. In the UR quadrant an example of a methodology to acquire knowledge of an interior view of It would be where the system is capable of reproducing and maintaining itself are studies on autopoiesis in the fields of chemistry and biology. An exterior view of It would employ methods of empiricism where you can observe the entity in part or as a whole, from outside of it. Most of the western scientific paradigm could be argued to have foundations in empiricism. The knowledge that characterises the UR quadrant is empiricism, and the entity of autopoiesis. Many statistical empirical studies in the field of IB studies for example, would fall in this quadrant in research design and framing. The combined effects of elements from the UL and LL quadrants in terms of human behaviour exhibited in relation to their environment is also reflected in the UR knowledge zone. The plural interobjective perspective reflects knowledge from network behaviour and system studies. This knowledge zone is framed in the Lower Right (LR) quadrant. Investigating system-of-systems, social autopoiesis, network theory and methodology could be said to be dominant methods of inquiry including systems theory. FAIB and sustainability science would for example, be a field of study that consistently employs system/network theories and theories on global governance in their research design and framing. In FAIB and sustainability science, systems are not mutually exclusive to each other. Rather, systems often interact if they are not in themselves interrelated. The knowledge zone of the LR quadrant as such, produces a systems-of-systems understanding to complex socio-ecological challenges. Perspectives and knowledge that characterises the LRL quadrant are necessarily broadest in perspective, encompassing / amalgamating all other perspectives. Figure 1 is an illustration of how the body of scientific knowledge as a whole is built and/or acquired. In terms of IDR research, the integral systems perspective can help situate / locate the expertise base of the individuals involved in the IDR project, and where for example, their knowledge can be complementary to another field, or applied in a practical context towards problem solving. As such, Figure 1 could be used as an IDR mapping tool in order to identify gaps in expertise needed for a context specific IDR project.

The following section will use $\mathrm{CATCH}$ as example IDR project and how an integral systems framework can be used to map resource and knowledge expertise complementarities. It illustrates

\footnotetext{
${ }^{4}$ Used in accordance to Koestler (1967), referring to an entity that is simultaneously a whole and a part.
} 
how the various actors and stakeholders in $\mathrm{CATCH}$ are interrelatedly engaged in the project to produce impactful / meaningful social and industry related changes.

\section{CATCH: An Example of an Interdisciplinary Project within Fisheries and Aquaculture International Business}

Atlantic Cod is a key species in the Norwegian seafood industry. In the years prior to the CATCH project, the share of cod in the total Norwegian export value of all wild-caught fish except mackerel and herring was $43 \%$ (NOK 5.6 billion) (Directorate of Fisheries, 2014). Cod is processed into many different product forms (e.g., fresh and frozen fillets and whole fish (headed and gutted), stock-fish, as well as salted and dry-salted cod, i.e. clip-fish) and is exported to a wide range of nations and market segments. The Norwegian domestic market for cod is also important, especially for fresh cod fillets. A key challenge for the cod industry is that many products such as frozen fillets/blocks and salted cod are produced and sold according to well-known specifications and can be characterised as commodities that are sold in spot markets where price-based competition prevail (Asche, Menezes \& Dias, 2007; Ottesen \& Grønhaug, 2005). The Norwegian cod industry faces many challenges not in the least the seasonal variability of the quality of cod, and its availability (Hermansen \& Eide, 2013). This in turn creates large variations in the price of cod and cod products. The Norwegian cod quota had increased by $142 \%$ to 472 thousand tons from 2008 to 2013. In the same period the average price (in round weight) to fishers has been reduced by $110 \%$ to less than $8 \mathrm{NOK} / \mathrm{kg}$. In addition, the seasonal pattern of cod landings from the coastal fleet with approximately $50 \%$ landed in the first three months of the year implies low prices to both fishers and processors/exporters in this period. Fishing and processing large quantities of cod in a short time often lead to poor quality, which may affect the reputation of Norwegian cod negatively (Dreyer et al., 2008). This is problematic because reputation is a key dimension of any competitive advantage that Norwegian cod and its suppliers might initially have had (Norwegian Seafood Council, 2017).

CATCH (2014-2018) is a Northern Norway founded IDR project funded by the Research Council of Norway that has as main objective to "catch" the maximal sustainable value of wild Atlantic cod based on live storage. The project is founded on the premise that cod products based on live storage have the highest potential to optimize the value of at least some parts of the cod resource. By keeping cod alive after capture, the long-standing and substantial logistical challenges associated with variations in supply volumes and quality (Ottesen \& Grønhaug, 2003) can be overcome (Olsen et al., 2013b; Dreyer et al., 2008). This opens up completely new possibilities for market-oriented and sustainable value chains for wild cod where consumers are provided with premium value and satisfaction and grocery retailers with long shelf-life, very high and uniform product quality and timely delivery. For fresh cod fillets in consumer packs for example, shelf life can be extended substantially through pre-rigor filleting and optimised packaging technology (Hansen et al., 2007). When cod is slaughtered on site, all by-products are retained and of premium quality which contributes to optimal resource utilisation. Moreover, when cod is stored live in the peak season (January-March), the supply of Norwegian cod is reduced in a period when large supply volumes of cod usually leads to low prices and poor profit margins for both fishers and the processing industry. In this way, live storage of cod can enhance the value of the Norwegian cod stock at the same time as it leads to a more sustainable use of this important natural resource.

The repeated lack of success in both research and business initiatives of live storage of cod in the past 20 years has been attributed to a non-systemic overview of technological bottlenecks related to fish capture and handling. Technological bottlenecks within the FAIB is serious due to that emerging industries such as that of capture-based cod aquaculture in Norway face complex challenges in terms of acquisition of expert knowledge and value-chain integration of processes (Vanpoucke, Vereecke \& Muylle, 2017; Porter, 1998). Thus, to exploit the substantial advantages of this market-oriented concept, a substantial and interdisciplinary research approach is required where natural and social sciences are closely integrated. The focus on differentiated products of high quality is also highly relevant in light of the increased competition from cheap substitutes to cod such as pangasius and double frozen cod products filleted in low cost countries such as China and marketed as chilled/fresh fillets in European supermarkets (Altintzoglou et al., 2012; Asche, Roll, \& Trollvik, 
2009). The increasing percentage of Norwegian cod exports that consists of fresh cod fillets is evidence that consumer segments and value chains have a willingness to pay for high quality cod.

In order to optimise research relevance and practical application, CATCH is inspired by actual value chains with highly motivated and committed industry partner (Ottesen, Grønhaug \& Johnsen, 2002). The selected cases are consumer packed products of chilled and frozen pre-rigor processed fillets. These cases represent very high value adding based on live storage of cod. The CATCHconsortium is interdisciplinary and international consisting of leading experts in all relevant fields. Through leadership and organisation, $\mathrm{CATCH}$ will strive to nurture a positive learning environment where known learning barriers in interdisciplinary research will be addressed.

$\mathrm{CATCH}$ is based on a sustainable and bio-economic perspective where the value of the cod resource is optimised through a high degree of value adding, improved logistics, minimal waste and interdisciplinary research along important value chains for cod products. It also supports key challenges faced in sustainable seafood consumption due to the increasing global consumption of seafood. The results from the project with its focus on market-oriented value adding and sustainability aims to bridge research and industry know-how. The targeted companies that might find the project results useful for their context may include companies and value chains that are not directly involved in live storage of cod.

\section{CATCH: An Integral Systems Approach}

Table 1 lists the research institutions and industry partners in $\mathrm{CATCH}$. There was a total of 15 institutional and enterprise collaborative partners in $\mathrm{CATCH}$, of which 8 were from the Norwegian FAIB industry. Each institution/industry partner had a core team of individuals dedicated to the project, depending on knowledge expertise. CATCH had to its advantage, subject / thematic coherence in capture-based aquaculture for cod and cod products in the Norwegian FAIB. Although with a specific focus on cod, the brief profiles of the stakeholders still illustrates the breadth of scope reflected in the coverage of its value chain.

Table 1. Institutional and industry collaborators in $\mathrm{CATCH}$

\begin{tabular}{|c|c|c|}
\hline & \multicolumn{2}{|l|}{ Industry partners } \\
\hline No. & Name & Core business \\
\hline 1 & Ballstadøy AS & Shipping vessel \\
\hline 2 & Coop Norge SA & $\begin{array}{l}\text { Cooperative supply chain in (mainly) } \\
\text { food trade }\end{array}$ \\
\hline 3 & Halvors Tradisjonsfisk AS & $\begin{array}{l}\text { North Norwegian coastal fishing fleet } \\
\text { and supplier of fish }\end{array}$ \\
\hline 4 & Multivac AS & Packaging equipment supplier \\
\hline 5 & Myre Havbruk AS & $\begin{array}{l}\text { Capture-based aquaculture enterprise in } \\
\text { Northern Norway }\end{array}$ \\
\hline 6 & Nergård AS & $\begin{array}{l}\text { Integrated fishery group founded in } \\
\text { Northern Norway }\end{array}$ \\
\hline 7 & Nic Haug AS & Producer, white fish products \\
\hline \multirow[t]{3}{*}{8} & Tommen Gram AS & Food packaging \\
\hline & Research/University partners & \\
\hline & Name & Country \\
\hline 9 & Aarhus School of Business & Denmark \\
\hline 10 & Duke University & USA \\
\hline 11 & $\begin{array}{l}\text { Handelshøyskolen (Business School), The Arctic University of } \\
\text { Norway (UiT) }\end{array}$ & Norway \\
\hline 12 & $\begin{array}{l}\text { Norges fiskerihøgskole (College of Fishery Science), The } \\
\text { Arctic University of Norway (UiT) }\end{array}$ & Norway \\
\hline 13 & $\begin{array}{l}\text { The Norwegian Institute of Food, Fisheries and Aquaculture } \\
\text { Research (NOFIMA) }\end{array}$ & Norway \\
\hline 14 & University of Stavanger & Norway \\
\hline 15 & Zurich University of Applied Sciences & Switzerland \\
\hline
\end{tabular}


The following section will outline the various fields of research for $\mathrm{CATCH}$, where the subject I themes of research are divided into 8 work pages (WP). These work pages are labelled WP1 to WP8. The WPs with its objectives and deliverables are described and then situated in an integral systems model for IDR project in Figure 2. Figure 2 maps the broad knowledge zones of CATCH from an integral systems perspective.

\subsection{Fields of research for $\mathrm{CATCH}$}

\subsubsection{WP1 Process technology: Harvesting methods in relation to fish physiology}

Apart from the biological rhythms of cod physiology through the seasons that affect muscle properties, the quality of wild-caught cod is affected not in the least by the fishing gear and onboard handling methods during harvest (Esaiassen, Akse \& Joensen, 2013; Joensen et al., 2005, 2004). When cod is kept alive after catch, inappropriate on-board handling, poor bleeding techniques (Olsen et al., 2013b) and pre-slaughter stress (Olsen et al., 2008) can be reduced or eliminated. Live stored cod will have natural variations in muscle properties throughout the year due to fish size, seasonal feeding patterns and spawning activity. Such variations in muscle properties have consequences for how the raw material will perform during processing, contributing towards the quality of the final products. Little is known about how cod, depending on season and fish size, reacts to capture and adaption to captivity; how it restores during live storage (e.g. how fast subcutaneous oedema caused by fishing gear and handling are healed); and, how fish suitable for storage and/or on-growing can best be separated from fish suitable for direct processing. Knowledge regarding inter-plant transport from live storage to instant stun and bleed systems is also addressed in WP1, with the intention to acquire and apply knowledge from the salmon farming industry. As such the overall objectives for WP1 is to optimise the slaughter process towards the more humane treatment of cod, eliminate poor bleeding and postpone the onset of rigor towards a higher quality product.

\subsubsection{WP2 Process technology: Storage methods}

Live storage of cod makes pre-rigor processing possible. This has advantages such as less fillet gaping and improved texture (Hultmann et al., 2016; Olsen, 2013b; Hultmann et al., 2012). Pre-rigor filleting also improves logistics and reduces cost at the processing plant as there is no need for raw material storage in wait of processing. Supermarket shelf life of chilled products can also be improved by days as the fillets are produced from a fresher raw material, compared to post rigor processing. Freezing and distribution of frozen raw material that is thawed and presented to the consumers as "refreshed", chilled fillet portions is a growing concept. Also in this case live cod, processed and frozen pre-rigor, is an interesting option. Another pre-rigor challenge of cod addressed in WP2 is the substantial shrinkage of fillets during storage, giving fillets an unusual, thicker shape. Inspired by research on salmon fileting (Skjervold et al., 2001), CATCH studied the quality properties of different parts of cod fillets. The overall objectives of WP2 is to optimize quality and yield of chilled fillet portions, fresh as well as thawed, obtained from cod caught alive at different times of the year and stored in net-pens without feeding.

\subsubsection{WP3 Bio-chemistry and fish physiology}

Due to the freshness of the raw material and low microbial activity, pre-rigor processed fillets is an optimal starting point for further extension of product shelf life for chilled ready-to-use consumer products (fresh/thawed). Raw fish products are open for contamination by a diverse mixture of bacteria during harvesting and processing, but little is known about the total microbial flora (Cambon-Bonavita et al., 2001; Suau et al., 1999) and how it may affect product quality and shelf life. It is also reported that bacteria can be inactivated by freezing (Bøknæes et al., 2000). Modified atmosphere packaging (MAP) by use of carbon dioxide $\left(\mathrm{CO}_{2}\right)$ has been shown to inhibit bacterial growth and negatively associated odour attributes during chilled storage (Rotabakk, Sivertsvik \& 
Birkeland, 2009; Hansen et al., 2007, 2009). As such, WP3 will conduct experiments at both laboratory and commercial scale with industry partners towards a deeper understanding of the cod live storage processes. Product yield and quality factors like shrinking, gaping and texture will be studied, together with sensory quality. Product shelf life will be addressed in cooperation with WP4.

Nofima, as research coordinator and collaborator, has suitable processing facilities for laboratory scale experiments, and well-established methods for sensory, chemical, physical (colour, texture) and microbiological analyses. Recent advances in the field of high-throughput sequencing of bacteria (16S rRNA analyses) facilitate analysis of the composition of a microbiota at very high resolution compared to traditional cloning and sequencing. Use of a real-time PCR for a quantification of specific bacteria will also be applied. These biological properties will be studied in relation to packaging methods, with the identification of ideal packaging materials, gas mixture, $\mathrm{CO}_{2}$ emitter and gas/product ratio, or vacuum/skin pack, to achieve optimal shelf life and quality. The overall objectives of WP3 would be to render an unbiased classification of bacteria where the bacteria can be analysed directly from the food matrix without any cultivation. This gives a more comprehensive picture of the total microbial biodiversity in fish than previously possible. This is expected to be very useful for odour description, to verify the effect on quality and shelf life.

\subsubsection{WP4 Marketing, product segmentation}

Seafood assortment and pricing at supermarkets reveals a lot about product competition and differentiation within a given food category. For example, detailed information about product/attribute assortment can reveal who the competitors are and what product attributes they emphasize in attempts to differentiate their offerings (Sogn-Grunvåg \&Young, 2013). It can also reveal whether unique attributes and price premiums for individual product attributes exist (Roheim, Gardiner \& Asche, 2007). How the unique quality of the various products based on live stored cod can best be communicated to provide superior customer value and gain the highest possible prices and how the product range develops over time, with deletions and additions, in terms of products, attributes and price premiums are of strategic interest for Norwegian suppliers of cod products based on the unique qualities optimized from live storage. Here, quality is defined as three distinct states of an offering's attributes' relative performance generated while producing, experiencing, and evaluating the offering. Sensory attributes such as taste, texture, odour and appearance are of vital importance for consumers' evaluation and choice of food. Consumers and their evaluations of the product, their buying behaviours and experiences will be critical to the success of cod products based on live storage. The overall objective for WP5 is to deeper understand the perceived quality, satisfaction, willingness to pay, and buying behaviour for different product forms, packaging formats/technologies and product information. The method applied was mainly an integrated quality approach (Tonkin et al., 2015; Grunert, 2002).

\subsubsection{WP5 Marketing, consumer behaviour}

In the area of marketing and consumer studies, the influence of extrinsic information on consumer choices such as brand name, price, country-of-origin, packaging, labelling, ethical and health information has been a research area for years (Wardy et al., 2018; Tudoran, Olsen \& Dopico, 2009; Maute \& Forrester, 1991). In recent years, multi-sensory marketing (Wiedmann et al., 2013; Hultén, 2011) has become a growing research area in consumer behaviour. Product experiences involve several sensory cues or types of information (Hasse \& Wiedmann, 2018; Hartman, 2016; Selnes \& Howell, 1999). Knowledge acquired in WP5 will contribute to current literature on how and why extrinsic attributes and information influence intrinsic and sensory attributes in food product evaluation (Wardy et al., 2017; Shifferstein, 2010), overall quality and satisfaction (Oliver, 2009). The overall objective of WP5 is to examine the relative contributions of multisensory inputs on consumer evaluation willingness to pay and choice. Studies of comparative products are necessary to obtain knowledge about the relative importance of attributes of cod compared to substitutes in target markets or segments. A particular focus will be on product colour since cod has several substitutes in the whitefish market. 


\subsubsection{WP6 Global value chain}

The live storage of cod faces challenges relating to how risk, costs and profits are shared in the value chain. In addition, live storage has to compete with the traditional value chains based on different capture technologies such as trawl, gillnets, long-line and Danish seine (Ottesen \& Grønhaug, 2003). In order to succeed, the live storage concept must perform better than these value chains in terms of ecological, economic and social sustainability (Eggert \& Tveterås, 2013). Little research has been conducted in this area. Accordingly, the overall objective for WP6 was to map the sustainability - and areas for improvement - for live storage of cod. WP6 will also explore how public management may hinder/stimulate the live storage concept and how this may influence the three dimensions of sustainability. Working closely with industry partners, alternative business models for organising the value chain, including vertical integration and intermediate markets was evaluated.

\subsubsection{WP7 Learning impact: Society-Science / University-Industry interface}

An IDR project inherently interfaces between society and science, research and applied practices. The key responsibilities of WP7 are to "pull together" implications of the findings from the different WPs by developing strategic recommendations for the seafood industry and to facilitate interdisciplinary learning both within the $\mathrm{CATCH}$ consortium and international researchers/ institutions working with live storage of fish. As such, WP7 will be an important link between the WP leaders, the international research partners, the industry partners and the reference group. In order to facilitate learning within the CATCH consortium, recommendations of how to overcome learning barriers in interdisciplinary research (Bruce et al., 2004) will be made. A crucial task in this respect is to encourage and stimulate participating researchers to value research diversity and to be sensitive to the dynamics when different research cultures and disciplines interact (Wall-Bassett, 2018; Reich \& Reich, 2006). This will be given explicit attention at workshops and project meetings. Joint fieldwork (or at least joint visits to other disciplines' fields) and interdisciplinary writing is also recommended as means to enhance interdisciplinary understanding and respect among the researchers involved. Joint development of value chain strategies for live stored cod is a good case for IDR work and writing. Other means to overcome communication barriers include frequent faceto-face meetings and video-conferences (Lync), particularly at the start of the project and at certain milestones when decisions need to be made (Lyall \& Meagher, 2007; Grønhaug \& Haukedal, 1997). The route from research results to practical application is a rather cumbersome one. This is particularly so for social sciences which usually contribute with conceptual knowledge that can be more difficult to adopt and use by the industry than the instrumental knowledge typically emerging from natural sciences (Grundvåg Ottesen \& Grønhaug, 2004; Grønhaug \& Haukedal, 1997). Research conducted by Nofima, indicates that the actual use of research can be enhanced by including users from the initial phases throughout the project. Another finding was that researchers' assistance in implementing results may enhance research use (Ottesen, Grønhaug \& Johnsen, 2002). The overall objective of WP7 is a practical one, in which actors ensure involvement in $\mathrm{CATCH}$ from initiation. This is to be achieved by continued close contact with relevant users.

\subsubsection{WP8 Knowledge dissemination and communication of results}

WP8 is devoted to disseminating the results from CATCH to relevant users of the results. This includes targeting academic and industry seminars, attending both academic conferences as well as trade fairs. A key premise will be that communication is directed at targeted user groups with appropriate media channels.

\section{Findings and Discussion}

$\mathrm{CATCH}$ is an IDR project that is situated in the broader field of FAIB and sustainability science. It addresses challenges at the interface of society and science, in close collaboration with the 
Norwegian fisheries and aquaculture industry sector. The research findings are intended to create change within industry practices, and in a longer-term perspective, to create a behavioural change (increased awareness of seafood sustainability and quality products for example) within the consumer market. Methodologically, its main method of analysis is empiricism and systems science, reflected in the UR and LR quadrants. The common denominator of scientific inquiry is an object in bio-chemistry, fish physiology or process technologies, with the dominant perspectives used reflected in the pronouns It (singular objective) and Its (plural interobjective). Figure 2 illustrates the various fields of research for $\mathrm{CATCH}$ and the knowledge zones utilized in order to address the FAIB challenges outlined in the project.

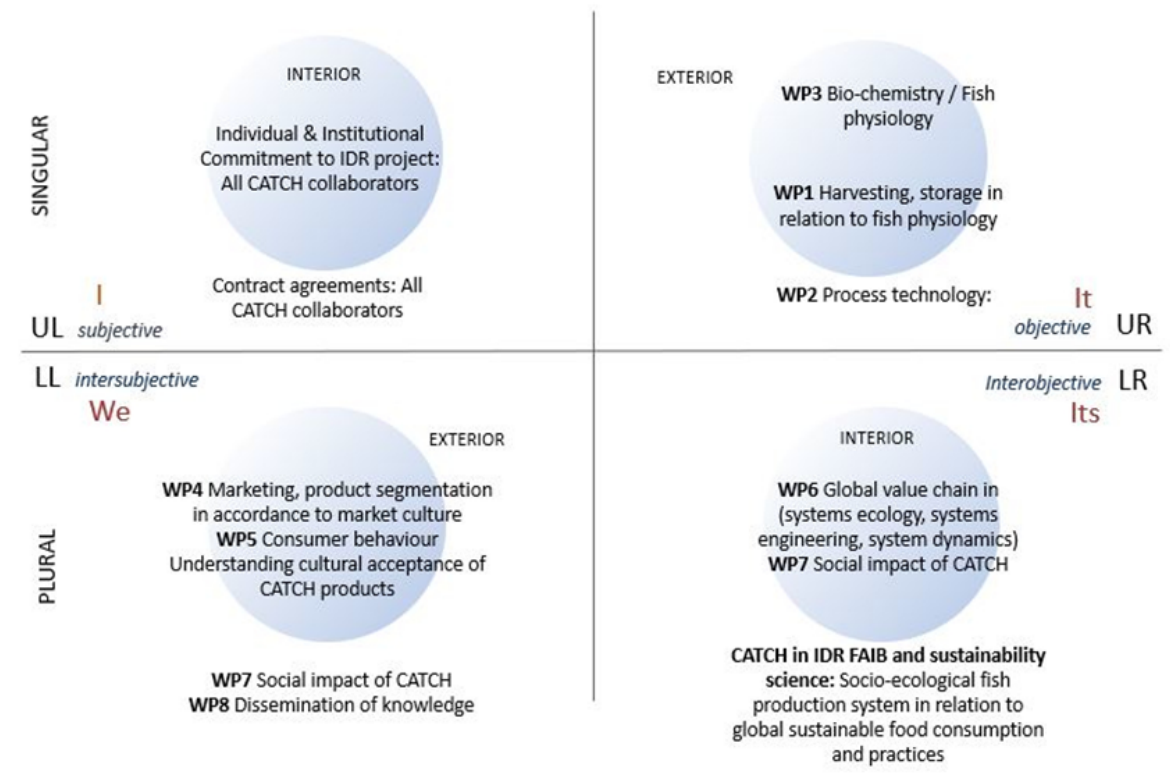

Figure 2. The work packages in $\mathrm{CATCH}$ and their knowledge zone contextualisation from an integral systems perspective.

Returning to the research questions and in answer to RQ1, Figure 2 illustrates how an integral systems approach can be used to unfold the complementary knowledge zones that characterises an IDR project. To have work packages 1 to 8 in address to the various units of analysis, from smaller to larger units of analysis is part of the inherent holonic, multi-perspective and multi-layered structure of an IDR project.

Most projects involve normative forms of communication between collaborators. Face-to-face meetings, virtual meetings, field studies, seminar exchanges and project phrase follow-ups and gate-way (in order to proceed to the next stage of $\mathrm{CATCH}$ research for example) evaluations between the collaborators are some examples of the types of meetings and activities that have taken place during the research processes of $\mathrm{CATCH}$. Some qualitative interviews conducted for $\mathrm{CATCH}$ are reflected in this section. The qualitative interviews, a series of 17 videos, can be found on the CATCH project webpage (CATCH, 2018).

A crucial project management strategy for CATCH however, and in answer to RQ2, is that $\mathrm{CATCH}$ had all collaborators onboard the project from the very beginning. This prevents or lessens the impact of unclear communication or intended direction/results of $\mathrm{CATCH}$ further on in the project. The commitment of all collaborators is reflected in the UL quadrant, where individual and organization commitment is highlighted. While committing to an IDR involves a sense of inner conviction, this inner conviction and philosophy is further materialized in the form of written contracts between all collaborators so that each participant and participating institution/enterprise 
knows explicitly (in writing), what is expected of them in terms of degree of involvement in CATCH, and delivery of results for $\mathrm{CATCH}$. While some scholars have argued that the very process of committing to certain deliverables from the beginning would inhibit the very creative processes of an IDR (Holmes et al., 2018), concretisation of a vision through writing could also be argued as a means of working towards actualisation.

A second observation for CATCH that answers RQs 1 and 2 is that the work within CATCH work packages themselves are cross-disciplinary, tapping into more than one type of knowledge zone:

"CATCH is a good example of how research institutes can work together with industry. Nofima has now launched efforts towards investigating how capture-based aquaculture of cod can make cod products available year-round, providing for a stable value-added supply of cod products that can secure better prices on the market." - Elisabeth Aspaker (Fiskeriminister, Norway)

"I've spent the last 5 to 7 years in $R \& D$ regarding technology development on capture-based aquaculture for cod. The main question for the companies that are onboard this project is how do we turn the business more profitable? CATCH put forth a system framework, so that we could look at all aspects of the phenomenon, not just capturing live cod, but we look into the processes from slaughter to freezing and packaging of the item. There are also variants of cod products from klippfisk or dried cod. With CATCH we also had the possibility to test our findings from various perspectives, biological, technological, right up to presenting the product to the consumers for the first time." - Kjell Midling (Senior Researcher, Nofima)

WP7 on the learning impact of $\mathrm{CATCH}$ at the interface between society and science, university and industry can be placed in knowledge zones in the LL and LR quadrants. Because learning takes place at the boundaries of where individuals meet and exchange views, those boundaries can be found at group level as well as system level where systems are inherently interactive. Other work packages that can span different types of knowledge zones include WP4 where consumer behaviour (We/They, plural intersubjective perspectives) is studied in relation to product segmentation (It, singular objective perspective).

Finally, in answer to RQ3, the social and pedagogical impact of IDR is not often times easy to measure. Still, for collaborators of $\mathrm{CATCH}$, the value of participating in an IDR is to gain insight into a field that on normative basis, one has little or no access to. Participating in an IDR project seems to deliver positive social learning experiences, and industry practice influences:

\footnotetext{
"The Norwegian Fishermen's Sales Organization needs to know what is happening in the industry. Capture-based aquaculture is a fairly new industry and much works needs to be done there. So it's important for us to be updated. In my opinion, what is the recommended storage time for cod is important. How long can cod remain in cages before they are slaughtered, so as to prevent blood clotting in the white flesh that lowers the quality of the cod when presented to the consumers is important to know." - Charles A. As (Advisor Råfisklaget Norge, The Norwegian Fishermen's Sales Organization)
}

\begin{abstract}
"For me what CATCH has done is to help me understand the Norwegian market for fresh cod and how people would like to buy and consume cod fillets. The results from $\mathrm{CATCH}$ show how we can deliver high quality cod fillets, rendering new market knowledge, and knowledge from micro-biology to live storage of cod up to slaughter techniques and packaging of fresh cod. CATCH has the main goal of helping industry bring high quality cod products to market. It offers insights into how that might be achieved. As of today, capture-based aquaculture from storage to table remains underresearched, and to enable a greater number of high-quality cod products to reach end consumers." - Morten Heide (Researcher, Nofima)
\end{abstract}

While some influences or impacts of $\mathrm{CATCH}$ as an IDR remain unmeasurable, reflected at best in qualitative interviews with individual collaborators of the project, an integral systems perspective of an IDR project such as $\mathrm{CATCH}$ helps collaborators and project managers map complementary knowledge zones. Figure 2 for example, can help identify knowledge gaps within the IDR project even prior to project commencement. It can also help steer the project using a 
systems overview of the project progress.

\section{Conclusion}

This study addresses the knowledge gap in a unified theoretical framework for the field of IDR studies. The contribution of this study has been twofold, including (i) consolidating the theoretical foundational knowledge of IDR through an integral systems theoretical perspective, and by using an empirical example of $\mathrm{CATCH}$, a project timely situated in a field that is inherently interdisciplinary in nature, with close industry collaboration, (ii) develop deeper insights into the management processes and strategy of an IDR project. The project CATCH draws upon the expertise knowledge of a total of 15 affiliated partners, both from industry and university sectors, in working towards broadening our understanding of preserving, if not enhancing cod products based on live capture and storage before slaughter.

The critique of the integral systems view to conducting IDR projects are similar in foundation to that of the study of natural phenomena. Due to that it is not possible for any one human mind, even a specified group of expert individuals, to understand all phenomena in its entirety, the IDR management process four-quadrant model reflected in Figures 1 and 2 are but an approximate knowledge and understanding of reality. Approximations in knowledge when applied to other working contexts can prove useful in the means in which the model can be adapted and render new insights into different IDR working contexts.

\section{References}

Adler, C., Hirsch Hadorn, G., Breu, T., Wiesmann, U., \& Pohl, C. (2018). Conceptualizing the transfer of knowledge across cases in transdisciplinary research. Sustainability Science, 13(1), 179-190.

Altintzoglou T., Nøstvold, B.H., Carlehög, M., Heide, M., Østli, J. \& Egeness, F.A. (2012) The influence of labelling on consumers' evaluations of fresh and thawed cod fillets in England, British Food Journal, 144(11), 1558-1570.

Asche, F., Menezes, R. \& Dias, J.F. (2007) Price transmission in cross boundary supply chains, Empirica, 34, 477-489.

Asche, F., Roll, K.H. \& Trollvik, T. (2009) New aquaculture species: The whitefish market. Aquaculture Economics and Management, 13(2), 76-93.

Banal-Estanol, A., Macho-Stadler, I., \& Perez-Castrillo, D. (2018). Endogenous Matching in University-Industry Collaboration: Theory and Empirical Evidence from the United Kingdom. Management Science, 64(4), 1591-1608.

Bark, R.H., Kragt, M.E. \& Robson, B.J. (2016). Evaluating an interdisciplinary research project: Lessons learned for organisations, researchers and funders. International Journal of Project Management, 34, 1449-1459.

Bowman, K. (2012). Integral scientific pluralism. Journal of Integral Theory and Practice, 7(1), 54-66.

Brandt, P., Ernst, A., Gralla, F., Luederitz, C., Lang, D., Newig, J., Reinert, F., Abson, D. \& von Wehrden, H. (2013). A review of transdisciplinary research in sustainability science. Ecological Economics, 92(C), 1-15.

Brown, B. (2018). Interdisciplinary research, European Review, 26(S2), S21-S29.

Bruce, A., Lyall, C., Tait, J. \& Williams, R. (2004) Interdisciplinary integration in Europe: the case of the Fifth Framework programme. Futures, 36, 457-470.

Bøknæs, N., Østerberg, C., Nielsen, J. \& Dalgaard, P. (2000). Influence of Freshness and Frozen Storage Temperature on Quality of Thawed Cod Fillets Stored in Modified Atmosphere Packaging. LWT - Food Science and Technology, 33(3), 244-248.

Cambon--Bonavita, M.A., Lesongeur, F., Menoux, S., Lebourg, A. \& Barbier, G. (2001) Microbial diversity in smoked salmon examined by a culture-independent molecular approach - a preliminary study. International Journal of Food Microbiology, 70(1-2), 179-187

Capra, F. (1985). Criteria of systems thinking. Futures, 17(5), 475-478.

Capra, F. (1997). The web of life: A new synthesis of mind and matter. Flamingo, London.

Capra, F., \& Luigi, P. (2014). The Systems View of Life: A Unifying Vision. Cambridge University Press, Cambridge, UK.

CATCH (2018). CATCH, market-oriented and sustainable value chains for cod product based on live storage, Norwegian Institute of Food, Fisheries and Aquaculture Research (NOFIMA). Nofima Projects. Internet resource at https://nofima.no/prosjekt/catch/. Retrieved 19 Dec. 2018.

Chomsky, N. (2011). Language and other cognitive systems. What is special about language? Language Learning and Development, 7(4), 263-278. 
Clark, S., Palis, F., Trompf, G., Terway, T., \& Wallace, R. (2017). Interdisciplinary problem framing for sustainability: Challenges, a framework, case studies. Journal of Sustainable Forestry, 36(5), 516-534.

Coase, R. (1937). The nature of the firm. Economica 4, 386-405

Darbellay, F. (2015). Rethinking inter- and transdisciplinarity: Undisciplined knowledge and the emergence of a new thought style. Futures, 65(C), 163-174.

Dewulf, A., François, G., Pahl-Wostl, C., \& Taillieu, T. (2007). A framing approach to cross-disciplinary research collaboration: Experiences from a large-scale research project on adaptive water management. Ecology and Society, 12(2): 14. Internet resource at http://www.ecologyandsociety.org/vol12/iss2/art14/. Retrieved 3 Dec. 2018.

Directorate of Fisheries (2014). Economic and biological key figures from Norwegian fisheries. Internet resource at https://www.fiskeridir.no/English/Fisheries/Statistics/Economic-and-biological-key-figures. Retrieved 13 Dec. 2018.

Dooley, L., \& Kirk, D. (2007). University-industry collaboration. European Journal of Innovation Management, 10(3), 316-332.

Dreyer, B.M., Nøstvold, B.H., Midling, K.Ø. \& Hermansen,Ø. (2008) Capture-based aquaculture of cod. In: Lovatelli, A. and Holthus, P.F. (eds.) Capture-based aquaculture. Global overview. FAO Fisheries Technical Paper, No. 508, Rome, FAO, 183-198.

Eggert, H. \& Tveterås, R. (2013). Productivity development in Icelandic, Norwegian and Swedish fisheries. Applied Economics, 45(6), 709-720.

Esaiassen, M., Akse, L. \& Joensen, S. (2013) Development of a catch-damage-index to assess the quality of cod at landing, Food Control, 29, $231-235$.

Esbjorn-Hargens, S. \& Zimmerman, M. (2009). Integral ecology: Uniting multiple perspectives on the natural world. Boston: Integral Books.

FAO (2018). The state of world fisheries, Food and Agriculture Organization of the United Nations, FAO 2018 report. Internet resource at http://www.fao.org/publications/card/en/c/19540EN. Retrieved 3 Dec. 2018.

Fazey, I., Bunse, L., Msika, J., Pinke, M., Preedy, K., Evely, A., Lambert, E., Hastings, E., Morris, S. \& Reed, M. (2014). Evaluating knowledge exchange in interdisciplinary and multi-stakeholder research. Global Environmental Change, 25(1), 204-220.

Floyd, J. (2008). Towards an Integral renewal of systems methodology for futures studies. Futures, 40(2), 138149.

Francois, Charles. (2006). Transdisciplinary unified theory.(Research Paper). Systems Research and Behavioral Science, 23(5), 617-624.

Gibbons, R. (2005). Four formal(izable) theories of the firm? Journal of Economic Behavior and Organization, 58(2), 200-245.

Grossman, S. \& Hart, O. (1986). The costs and benefits of ownership: a theory of vertical and lateral integration. Journal of Political Economy 94, 691-719.

Grunert, K.G. (2002) Current issues in the understanding of consumer food choice, Trends in Food Science and Technology, 13, 275-285.

Grundvåg Ottesen, G. \& Grønhaug, K. (2004). Barriers to practical use of academic marketing knowledge. Marketing Intelligence \& Planning, 22(5), 520-530.

Grønhaug, K. \& Haukedal, W. (1997) The cumbersome route from research data to knowledge use, Creativity and Innovation management, 6(3), 151-160.

Haase, J., \& Wiedmann, K. (2018). The sensory perception item set (SPI): An exploratory effort to develop a holistic scale for sensory marketing. Psychology \& Marketing, 35(10), 727-739.

Halliday, M., \& Matthiessen, C. (2014). Halliday's introduction to functional grammar (4.th ed.). Abingdon, Oxon; New York: Routledge.

Hansen, A., Mørkøre, A., Rudi, K., Olsen, E. \& Eie, T. (2007). Quality Changes during Refrigerated Storage of MA-Packaged Pre -rigor Fillets of Farmed Atlantic Cod (Gadus morhua L.) Using Traditional MAP, CO 2 Emitter, and Vacuum. Journal of Food Science, 72(9), M423-M430.

Hansen, A., Mørkøre, T., Rudi, K., Rødbotten, M., Bjerke, F., \& Eie, T. (2009). Quality Changes of Prerigor Filleted Atlantic Salmon ( Salmo salar L.) Packaged in Modified Atmosphere Using CO 2 Emitter, Traditional MAP, and Vacuum. Journal of Food Science, 74(6), M242-M249.

Hartman, L. (2016). Extra sensory perceptions. Food Processing, 77(8), 39.

Hermansen, $\varnothing$. \& Eide, A. (2013). Bioeconomics of capture-based aquaculture of cod (Gadus Morhua). Aquaculture Economics \& Management, 17(1), 31-50.

Holmes, H., Gregson, N., Watson, M., Buckley, A., Chiles, P., Krzywoszynska, A., \& Maywin, J. (2018). Interdisciplinarity in Transdisciplinary Projects: Circulating Knowledges, Practices and Effects. disP - The Planning Review, 54:2, 77-93, DOI: 10.1080/02513625.2018.1487646

Hultén, B. (2011). Sensory marketing: The multi-sensory brand-experience concept. European Business Review, 23(3), 256-273. 
Hultmann, L., Tobiassen, T., Aas-Hansen, \&., Phu, T., \& Rustad, T. (2016). Muscle quality and proteolytic enzymes of farmed Atlantic cod (Gadus morhua ) during storage: Effects of pre-slaughter handling and increased storage temperature. Journal of Aquatic Food Product Technology, 25(4), 540-554.

Hultmann, L., Phu, T.M., Tobiassen, T., Aas-Hansen, $\varnothing$. \& Rustad, T. (2012). Effects of pre-slaughter stress on proteolytic enzyme activities and muscle quality of farmed Atlantic cod (Gadus morhua). Food Chemistry, 134(3), 1399-1408.

Huutoniemi, K., Klein, J., Bruun, H. \& Hukkinen, J. (2010). Analyzing interdisciplinarity: Typology and indicators. Research Policy, 39(1), 79-88.

Joensen, S., Akse, L., Bjørkevoll, I. \& Mathisen, I. (2004) Kvalitetsforbedring av råstoff til saltfisk-produksjon Fangstskader på råstoffet og konsekvenser for kvaliteten på saltfisken. Norwegian Institute of Food, Fisheries and Aquaculture Research (NOFIMA), Nofima, Rapport 16/2004. Norway.

Joensen, S., Akse, L., Bjørkevoll, I. \& Mathisen, I. (2005) Kvalitetsforbedring av råstoff til tørrfiskproduksjon fangstskader på råstoffet og konsekvenser for kvaliteten på tørrfisken. Norwegian Institute of Food, Fisheries and Aquaculture Research (NOFIMA), Nofima, Rapport 02/2005. Norway.

Klein, J. (2008). Evaluation of Interdisciplinary and Transdisciplinary Research: A Literature Review. American Journal of Preventive Medicine, 35(2), S116-S123.

Koestler, A. (1967). The ghost in the machine. London, UK: Hutchinson.

Krütli, P., Stauffacher, M., Flüeler, T., \& Scholz, R. (2010). Functional-dynamic public participation in technological decision-making: Site selection processes of nuclear waste repositories. Journal of Risk Research, 13(7), 861-875.

König, B., Diehl, K., Tscherning, K. \& Helming, K. (2013). A framework for structuring interdisciplinary research management. Research Policy, 42(1), 261-272.

Jahn, T., Bergmann, M. \& Keil, F. (2012). Transdisciplinarity: Between mainstreaming and marginalization. Ecological Economics, 79(C), 1-10.

Lam, M. (2016). The Ethics and Sustainability of Capture Fisheries and Aquaculture. Journal of Agricultural and Environmental Ethics, 29(1), 35-65.

Lee, YS. (2000) The sustainability of university-industry research collaboration: An empirical assessment, The Journal of Technology Transfer, 25(2), 111-133.

Lemaine, G., MacLeod, R., Mulkay, M. \& Weingart, P. (1976). Perspectives on the emergence of scientific disciplines. The Hague: Mouton; Paris: Aldine.

Lyall, C. \& Meagher, L. (2007) A short guide to building and managing interdisciplinary research teams, ISSTI Briefing Note (Number 3). Internet resource at https://jlesc.github.io/downloads/docs/ISSTI_Briefing_Note_3Building_Interdisicplinary_Research_Teams.pdf. Retrieved 14 Dec. 2018.

Maute, M. \& Forrester, W. (1991). The Effect of Attribute Qualities on Consumer Decision Making: A Causal Model of External Information Search. Journal of Economic Psychology, 12(4), 643.

Mascarenhas, C., Ferreira, J. J. \& Marques, C. (2018). University-industry cooperation: A systematic literature review and research agenda. Science and Public Policy, Science and Public Policy, 45(5): 708-718, https://doi-org.ezproxy.ub.gu.se/10.1093/scipol/scy003

Metzger, N. \& Zare, R.N. (1999). Interdisciplinary research: From belief to reality, Science, 29 Jan. 1999 , vol. 283, issue 5402, pp. 642-643. DOI: 10.1126/science.283.5402.642

Mårtensson, P., Fors, U., Wallin, S-B., Zander, U. \& Nilsson, G. (2016). Evaluating research: A multidisciplinary approach to assessing research practice and quality. Research Policy, 45(3), 593-603.

Norwegian Seafood Council (2017). New country of origin mark for Norwegian seafood, Norwegian Seafood Council. Internet resource at https://en.seafood.no/news-and-media/news-archive/new-country-of-originmark-for-norwegian-seafood/. Retrieved 13 Dec. 2018.

Oliver, R. (2009). Satisfaction: A Behavioral Perspective on the Consumer. New York: M.E. Shape

Olsen, D. S., Borlaug, S. B., Klitkou, A., Lyall, C. \& Yearly, S. (2013a). A better understanding of interdisciplinary research in climate change, NIFU working paper 2013-15. NIFU, Nordic Institute for Studies in Innovation, Resarch and Education, Norway. Internet resource at http://hdl.handle.net/11250/2358611. Retrieved 3 Dec. 2018.

Olsen, S. H., Sørensen, N.K., Larsen, R., Elvevoll, E.O. \& Nilsen, H. (2008). Impact of pre-slaughter stress on residual blood in fillet portions of farmed Atlantic cod (Gadus morhua): Measured chemically and by Visible and Near-infrared spectroscopy. Aquaculture, 284(1), 90-97.

Olsen, S. H., Tobiassen, T., Akse, L., Evensen, T.H. \& Midling, K.Ø. (2013b). Capture induced stress and live storage of Atlantic cod (Gadus morhua) caught by trawl: Consequences for the flesh quality. Fisheries Research, 147, 446-453.

Ottesen, G.G., Grønhaug, K. \& Johnsen, O. (2002) Benefiting from commissioned research: the role of researcher-client cooperation, Creativity and Innovation Management, 11(2), 88-97.

Ottesen, G.G. \& Grønhaug, K. (2003) Primary uncertainty in the seafood industry: an exploratory study of how processing firms cope, Marine Resource Economics, 18(4), 363-371. 
Ottesen, G.G. \& Grønhaug, K. (2005) Exploring how managers conceive and practice market orientation in near to "perfect" food commodity markets, Journal of Food Products Marketing, 11(2), 59-74.

Pischke, E., Knowlton, C., Phifer, J., Gutierrez Lopez, L., Propato, T., Eastmond, A., Souza, T., Kuhlberg, M., Picasso Risso, V., Veron, S., Garcia, C., Chiappe, M. \& Halvorsen, K. (2017). Barriers and Solutions to Conducting Large International, Interdisciplinary Research Projects. Environmental Management, 60(6), 1011-1021.

Pohl C. \& Hirsch Hadorn, G. (2007) Principles for designing transdisciplinary research. Proposed by the Swiss Academies of Arts and Sciences. Oekom, Munich. Internet resource at http://www.transdisciplinarity.ch/tdnet/Publikationen/Publikationen-td-

net/mainColumnParagraphs/08/text_files/file2/document/knowledgeforms_principles.pdf. Retrieved 12 Dec. 2018.

Pohl, C. \& Hirsch Hadorn, G. (2008). Methodological challenges of transdisciplinary research. Natures Sciences Sociétés 16, 111-121. Internet resource at https://www.nssjournal.org/articles/nss/abs/2008/02/nss8204/nss8204.html. Retrieved 12 Dec. 2018.

Porter, M. (1998). Competitive advantage: Creating and sustaining superior performance (Updated ed.). USA, New York: Free Press.

Qin, J., Lancaster, F., \& Allen, B. (1997). Types and Levels of Collaboration in Interdisciplinary Research in the Sciences. Journal of the American Society for Information Science, 48(10), 893-916.

Rau, H., Goggins, G. \& Fahy, F. (2018). From invisibility to impact: Recognising the scientific and societal relevance of interdisciplinary sustainability research. Research Policy, 47(1), 266-276.

Reich, S.M. \& Reich, J.A. (2006) Cultural competence in interdisciplinary collaborations: a method for respecting diversity in research partnerships, American Journal of Community Psychology, 38, 51-62.

Roheim, C.A., Gardiner, L. \& Asche, F. (2007) Value of brands and other attributes: hedonic analysis of retail frozen fish in the UK, Marine Resource Economics, 22(3), 239-253.

Roux, D.J., Stirzaker, R., Breen, C., Lefroy, E.C. \& Cresswell, H. (2010). Framework for participative reflection on the accomplishment of transdisciplinary research programs. Environmental Science and Policy, 13(8), 733-741.

Roy A.C., Curie, A., Nazir, T., Paulignan, Y., des Portes, V., Fourneret, P., Deprez, V. (2013) Syntax at hand: Common syntactic structures for actions and language, PLoS ONE 8(8): e72677. https://doi.org/10.1371/journal.pone.0072677

Scandura, A. (2016). University-industry collaboration and firms' R\&D effort. Research Policy, 45(9), 19071922.

Selnes, F. \& Howell, R. (1999). The effect of product expertise on decision making and search for written and sensory information. Advances In Consumer Research, Vol 26, 26, 80-89.

Shifferstein, H.N.J. (2010). From salad to bowl: The role of sensory analysis in product experience research. Food Quality and Preference, 21, 1059-1067.

Skjervold, P.O., Fjæra, S.O., Østby, P. B., Isakson, T., Einen, O., Taylor, R. (2001) Properties of salmon flesh from different locations on pre- and post-rigor fillets, Aquaculture 201, 91-196.

Sogn-Grundvåg, G. \& Young, J.A. (2013). Commoditization in food retailing: is differentiation a futile strategy? Journal of Food Products Marketing, 19(3),139-152.

Steinmo, M. (2015). Collaboration for innovation: A case study on how social capital mitigates collaborative challenges in university-industry research alliances. Industry and Innovation, 22(7), 1-28.

Stokols, D., Fuqua, J., Gress, J., Harvey, R., Phillips, K., Baezconde-Garbanati, L., Unger, J., Palmer, P., Clark, M.A., Colby, S.M., Morgan, G. \& Trochim, W. (2003). Evaluating transdisciplinary science, Nicotine and Tobacco Research, 5(1): S21-S39

Stokols, D., Misra, S., Moser, R.P., Hall, K.L. \& Taylor, B.K. (2008). The ecology of team science: Understanding contextual influences on transdisciplinary collaboration. American Journal of Preventive Medicine, 35(2), S96-S115.

Suau, A., Bonnet, R., Sutren, M., Godon, J.J., Gibson, G.R., Collins, M.D. \& Dore, J. (1999). Direct analysis of genes encoding 16S rRNA from complex communities reveals many novel molecular species within the human gut, Applied Environmental Microbiology, 65(11), 4799-4807

Szostak, R. (2015). Interdisciplinary and transdisciplinary multimethod and mixed methods research. In S. Hesse-Biber, R. Johnson, \& R. Szostak, R. (eds). The Oxford Handbook of Multimethod and Mixed Methods Research Inquiry. Oxford University Press, Chapter 51. DOI: 10.1093/oxfordhb/9780199933624.013.51

Thompson, S., \& Valentinov, V. (2017). The neglect of society in the theory of the firm: A systems-theory perspective. Cambridge Journal of Economics, 41(4), 1061-1085.

Tonkin, E., Wilson, A., Coveney, J., Webb, T., \& Meyer, S. (2015). Trust in and through labelling - a systematic review and critique. British Food Journal, 117(1), 318-338.

Tudoran, A., Olsen, S.O. \& Dopico, D.C. (2009). The effect of health benefit information on consumers health value, attitudes and intentions. Appetite, 52(3), 568-579. 
Turner, V., Benessaiah, K., Warren, K., \& Iwaniec, S. (2015). Essential tensions in interdisciplinary scholarship: Navigating challenges in affect, epistemologies, and structure in environment-society research centers. Higher Education, 70(4), 649-665.

Vahlne, J., \& Johanson, J. (2013). The Uppsala model on evolution of the multinational business enterprise from internalization to coordination of networks. International Marketing Review, 30(3), 189-210.

Vahlne, J., \& Johanson, J. (2017). From internationalization to evolution: The Uppsala model at 40 years. Journal of International Business Studies, 48(9), 1087-1102.

Vanpoucke, E., Vereecke, A., \& Muylle, S. (2017). Leveraging the impact of supply chain integration through information technology. International Journal of Operations \& Production Management, 37(4), 510-530.

Villasante, S., Rodríguez, D., Antelo, M., Quaas, M. \& Österblom, H. (2011). The Global Seafood Market Performance Index: A theoretical proposal and potential empirical applications. Marine Policy, 36(1), 142152.

von Bertalanffy, L. (1968). General system theory: Foundations, development, applications. New York, George Braziller.

Wagner, C.S., Roessner, J.D., Bobb, K., Klein, J.T., Boyack, K., Keyton, J., Rafols, I. \& Börner, K. (2011). Approaches to understanding and measuring interdisciplinary scientific research (IDR): A review of the literature. Journal of Informetrics, 5(1), 14-26.

Wall-Bassett, E. D., Hegde, A. V., Craft, K. L. \& Oberlin, A. (2018). Using Campinha-Bacote's framework to examine cultural competence from an interdisciplinary international service learning program. Journal of International Students, 8(1), 274-283.

Wardy, W., Jack, A., Chonpracha, P., Alonso, J., King, J. \& Prinyawiwatkul, W. (2018). Gluten-free muffins: Effects of sugar reduction and health benefit information on consumer liking, emotion, and purchase intent. International Journal of Food Science \& Technology, 53(1), 262-269.

Wardy, W., Chonpracha, P., Chokumnoyporn, N., Sriwattana, S., Prinyawiwatkul, W. \& Jirangrat, W. (2017). Influence of Package Visual Cues of Sweeteners on the Sensory-Emotional Profiles of Their Products. Journal of Food Science, 82(2), 500-508.

Wesselink, A. (2009). The emergence of interdisciplinary knowledge in problem-focused research. Area, 41(4), 404-413.

Whorf, B. \& Carroll, J. (1974). Language, thought and reality: Selected writings of Benjamin Lee Whorf $\left(11^{\text {th }}\right.$ edition). Cambridge, Mass.: MIT P.

Wiedmann, K., Hennigs, N., Klarmann, C., \& Behrens, S. (2013). Creating Multi-Sensory Experiences in Luxury Marketing. Marketing Review St. Gallen, 30(6), 60-69.

Wilber, K. (2000). A theory of everything. Boston: Shambhala.

Wilber, K. (2006). Integral spirituality. Boston: Shambhala. 